\title{
老人性円背における臨床的検討
}

一一第 2 報——

済生会下関病院整形外科

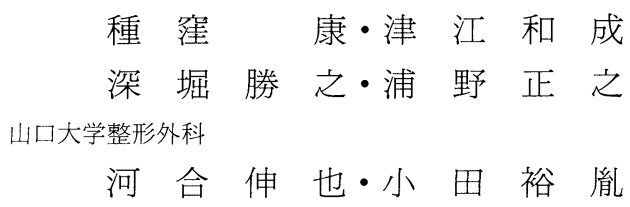

\section{Clinical Investigation of Senile Round Back}

by

\section{Koh Tanekubo, Kazunari Tsue, Katsuyuki Fukahori and Masayuki Urano}

Department of Orthopedic Surgery, Saiseikai Shimonoseki Hospital, Yamaguchi, Japan

\section{Shinya Kawai and Hirotsugu Oda}

Department of Orthopedic Surgery, Yamaguchi University

School of Medicine, Yamaguchi, Japan

Senile round backs are mostly due to osteoporosis, wedge vertebrae and narrowing of the disc, and often associated with back pain. The accurate causes of the back pain are still obscure. 101 cases of senile round back were investigated to clarify the mechanism of the back pain. They were classified into 2 groups according to the types of round back, namely 1) the upper group in which the apex of kyphosis is located in the middle thoracic spine, and 2) the lower group in which the apex is the thoracolumbar junction.

Most of the cases in two groups demonstrated similar clinical symptoms. The pain was located at bilateral paravertebral regions including the area close to lumbar spinal process and at the gluteal region.

Facet block with xylocain at the lumbar spine produced relief of the pain in $76 \%$ of 34 cases, which suggests that one of the main causes of chronic back pain of senile round back originates from the lumbar facet joints.

\section{はじめに}

60 才以上の老人の約 $70 \%$ 円背を呈し,腰背部に慢 性疼痛を有するものが多い. 円背の原因としては, 春 椎骨粗鬆症による椎体の楔状化, 変形性脊椎症による 椎間板の狭小化, 静力学的バランスを保つための腰背 部の筋群の筋力不全などが考えられるが，一方慢性疼 痛の主因が何であるかは，いまだに明確にされていな い.今回われわ机は 60 才以上で円背を呈し, 腰背部痛
を訴える老人の全脊柱 $\mathrm{X}$ 線所見，臨床症状などから， 腰背部痛の由来について検討したので報告する.

対

象

症例数は 101 例で, 男性 19 例, 女性 82 例であり, 年令は 60 才から 92 才, 平均 73.7 才であった。

結 果

立位全脊柱 $\mathrm{X}$ 線写真より, 胸腰椎後弯角, 腰椎前弯 


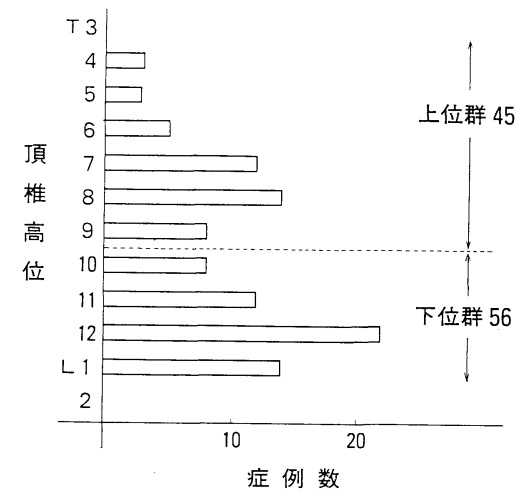

図 1 後弯頂椎高位分布

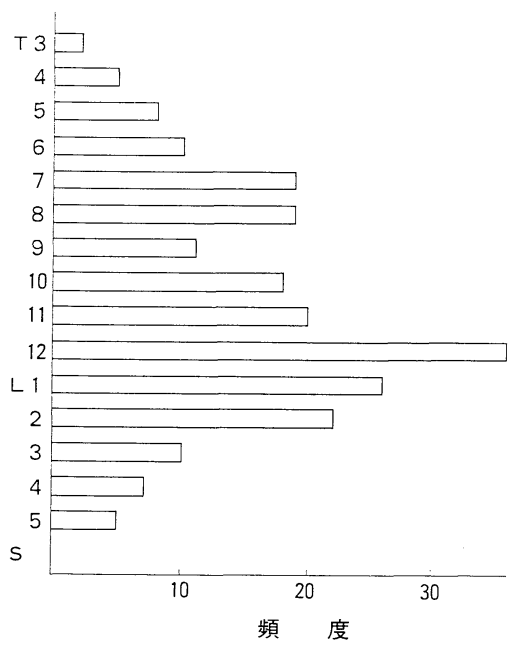

図 2 楔状椎の高位と頻度

角，仙骨基底面傾斜角を計測したところ，後弯角は平 均 $55.8^{\circ}$, 前弯角は平均 $48.7^{\circ}$, 仙骨基底面傾斜角は平 均 $28.9^{\circ}$ であった。

後弯頂椎の高位分布は二峰正を呈し（図 1 ）, 第 7 , 8 胸椎を中心とする上位後弯群 45 例 $(44.5 \%$ ) と胸腰 椎移行部を中心とする下位後弯群 56 例 (55.5\%) とに 分かれた。

この 2 群で胸腰椎後弯角, 腰椎前弯角を比較したと ころ，いずれも有意差がなかった，仙骨基底面傾斜角 は上位群の方が有意に大きかった（上位群：31.2土 $11.94^{\circ}$ ，下位群：26.63土10.96 $\left.， \mathrm{p}<0.05\right)$ が，いずれ も正常に比べるとやや小さかった.

脊椎前方要素の変形については, 椎体の楔状椎化は 胸腰椎移行部に多発し, 次いで中位胸椎にも比較的多

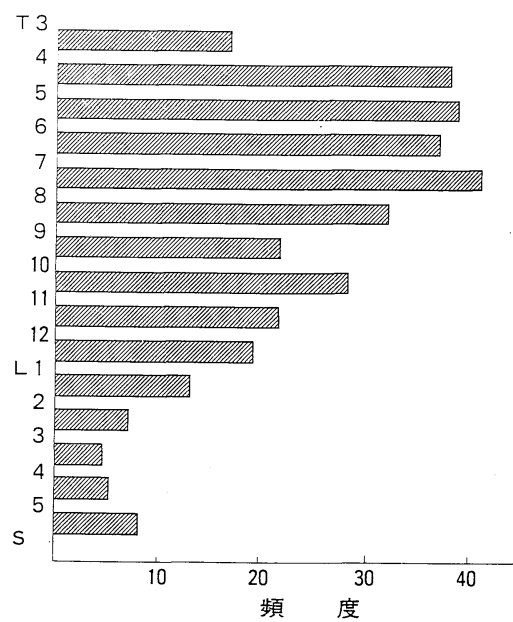

図 3 椎間板狭小の高位と頻度

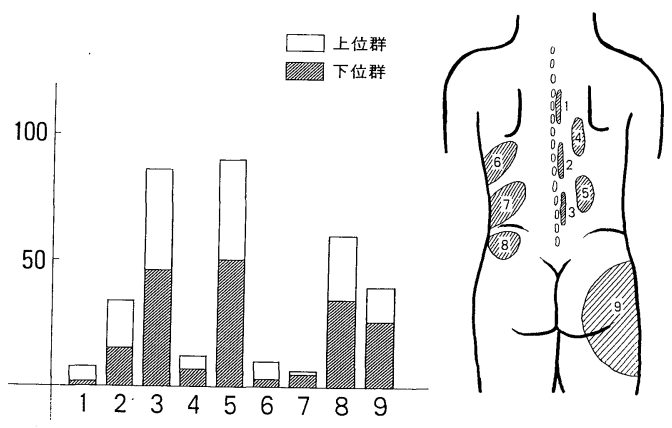

図 4 臨床症状

く二峰性分布を示した(図 2 )。椎間板狭小化は中位胸 椎に多くみられた(図 3 )。これを上位群と下位群とで 比較すると, 楔状椎は, 上位群平均 1.6 椎, 下位群平 均 2.6 椎であり, 有意に下位群の方が多く, 椎間板狭 小では, 上位群平均 5.3 椎間, 下位群平均 3.2 椎間で あり，上位群の方が有意に多かった．胸腰椎の骨萎縮 度を慈大式分類で判定したところ下位群の方が骨粗鬆 症の程度が強かった。

臨床症状としては図 4 に示したごとく，上位群，下 位群ともに, $\mathrm{L}_{3}$ を中心とした傍脊柱筋部, 腰椎棘突起 間外側部および慰部の疼痛を訴えるものが多く, 胸椎 部の疼痛や，下肢の神経症状を有する例はまれであっ た。

今回, 棘突起外側部の圧痛点を Merkmal として, 1 


\begin{tabular}{ll}
\hline $\mathrm{T}_{12-} \mathrm{L}_{1}$ & 1 例 \\
$\mathrm{L}_{1-2}$ & 2 \\
$\mathrm{~L}_{1-2,2-3}$ & 1 \\
$\mathrm{~L}_{2-3}$ & 5 \\
$\mathrm{~L}_{2-3}, 3-4$ & 9 \\
$\mathrm{~L}_{3-4}$ & 11 \\
$\mathrm{~L}_{3-4,4-5}$ & 3 \\
$\mathrm{~L}_{4-5}$ & 1 \\
$\mathrm{~L}_{4-5}, 5-\mathrm{S}$ & 1 \\
\hline
\end{tabular}

図 5 椎間関節ブロック高位

椎間または 2 椎間に椎間関節ブロックを行った. 正確 を期すため，椎間関節造影を行ったのち，同部に $1 \%$ リドカインの $0.5 \sim 1 \mathrm{ml}$ を注入した.ブロックの高位は 図 5 に示したごとく, $\mathrm{L}_{3-4}$ の 1 椎間に行ったもの, $\mathrm{L}_{2-3}$, $\mathrm{L}_{3-4}$ の 2 椎間に行ったものが多かった.ブロックのの ち疼痛の消失したものを有効, 疼痛の半減したものを やや有効，変化のなかったものを無効としたところ， 14 例 $(41.2 \%)$ が有効, 11 例 (32.4\%) がやや有効, 9 例 $(26.4 \%)$ が無効であった。

\section{考察}

腰背痛の原因としては，1）骨性疼痛，2）椎間板， 後縦靶帯性疼痛，3）根性疼痛，4）椎間関節性疼痛, 5) 筋, 筋膜性疼痛がある ${ }^{1)}$ が, 今回の調査結果から, 椎体, 椎間板の変化の程度が違っても, 臨床症状はほ ぼ同様であることから, 春椎前方要素由来の疼痛は考 えがたく，また根性特有の痛みをもつ症例もほとんど みられないことから, 老人性円背の腰背痛, 臀部痛は 主として脊椎後方要素由来，すなわち椎間関節性また は筋・筋膜性の疼痛と考え，今回椎間関節ブロックを 行ったところ $73.6 \%$ に疼痛の消失ないし, 軽減がみら れ，老人性円背の腰背痛の原因として，かなりの頻度 で椎間関節症が関与しているものと考えられた。

脊髄神経後内側枝より支配される椎間関節の退行性 変化は一般に脊椎前方要素の変化に引き続きおこると されており ${ }^{2) \sim 4)}$, 胸椎に比し, 可動性の大きい腰椎にお いて椎間関節症が生じやすいことは想像に難くない. 一般に腰痛患者に対する椎間関節ブロックの有効率は 50〜 60\%とされており ${ }^{4)}$, 関節症性変化の進んだ老人性 円背においてこれを上回ったことは当然の結果とも言 えよう.今後さらに症例を加え検討する予定であるが， また筋・筋膜性疼痛についても別の角度より検討した い.

\section{ま と め}

1. 老人性円背を呈する症例 101 例についてX線学 的および臨床的検討を加えた。

2. 中位胸椎を頂椎とする上位円背群と胸腰椎移行 部を頂椎とする下位円背群の 2 群に分かれた。

3. 臨床症状は両群に差がなく，ともに腰部傍脊柱 筋部, 腰椎棘突起間外側部, および䯈部の疼痛が多か った。

4. 今回 34 例に椎間関節ブロックを行い, 25 例 (73.6\%) に疼痛の消失ないし軽減をみた。

\section{参 考 文 献}

1）片岡 治：腰痛 - 坐骨神経痛. 図説臨床整形外科講 座, 3:50-77, 1984.

2) Nikolai Bogduk: The Innervation of the Lumbar Spine, SPINE, 8: 286-293, 1983.

3) Nikolai Bogduk: The anatomy of the so-called "articular nerves" and their relationship to facet denervation in the treatment of low back pain. J. Neurosurg, 51 : 172-177, 1979.

4) Vert Mooney: The Facet Syndrome, Clinical orthopaedics, Number 115: 149-156, 1976.

質 問浜脇病院 大森 啓司

上位型と下位型で椎間関節ブロックの場所が違うも のか?

圧痛部位は不確実と思われるが？

解 答済生会下関病院 種窪 康

今回の調查においては上位型と下位型でブロックの 高位に有位差はみられなかった。現在のところ圧痛部 位と椎間関節症のレベルは相関性が高いと考えている。

質 問総合背損センター 佐々木邦雄

(1) 後方の測定はC Cobb 法で行われたのですか.

(2) 後方の頂点で上位, 下位群に分けられています が，下位群は end vertebra が $\mathrm{L}_{2-3}, 3-4$ にくる例が多 いと思う. facet blockでの effectiveness と kyphosis の end vertebraの関係はいかがでしたか.

解 答済生会下関病院 種窪 康

(1) Cobb 法で行いました.

(2) Endvertebra $と$ facet block $の$ effectiveness $の$ 関係は今回調査しておりません。 